\title{
一酸化炭素の水素化反応における 選択性制御
}

\section{荒井弘 通 ${ }^{*}$}

\section{Product Control in the Hydrogenation of Carbon Monoxide.}

Hiromichi ARAI*

A broad range of hydrocarbons and oxygenated products can be synthesized catalytically from CO and $\mathrm{H}_{2}$. In this brief review it is discussed how catalyst composition governs the distribution of products formed. As the mechanisms are very important for the design of catalytic reaction, the mechanistic hypotheses developed since 1978 are presented here with reference to discussions of organometallic chemistry, particularly non-dissociation and dissociation of carbon monoxide on adsorption, dihydrogen activation, and bond formation of carbon-carbon, carbon-hydrogen and oxygn-hydrogen.

\section{1. はじめに}

$\mathrm{C}_{1}$ 化学における選択性制御の研究が盛んに行われ, 多くの制御方法に関する知見が蓄積されつつある

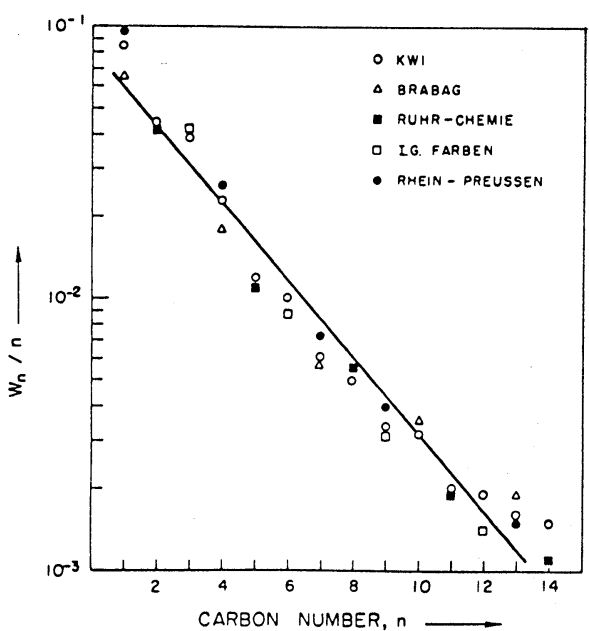

Fig. 1 Hydrocarbon distributions for commercial iron catalysts.

* 九州大学大学院総合理工学研究科材料開発工学専攻

* Graduate School of Engineering Sciences,

Department of Materials Science and Technology, Kyushu University
標生成物は化学原料から燃料に到るまで数多くある。生 成物の分子構造の観点から，C-O を切断して水素化し たアルキル基と $\mathrm{C}-\mathrm{O}$ を切断しない水酸基の両方を含む 含酸素化合物の合成は非常に難しい2 4)。1920 年代に開 発された Fischer-Tropsch 法は原料として一酸化炭素 と水素からなる合成ガスを使用し，触媒として鉄系の固 体触媒を用いた。この生成物分布は図 1 に示すょうに Schulz-Flory 則に従い，炭素数と $\mathrm{W}_{\mathrm{n}} / \mathrm{n}$ (ただし $\mathrm{W}_{\mathrm{n}}$ ： 炭素数 $\mathrm{n}$ の重量分率）もしくは連鎖成長度と選択性（図 2）は互いに依存する ${ }^{5 \sim 7)}$ 。たとえば $\mathrm{C}_{2}$ は $30 \%$ 以上合

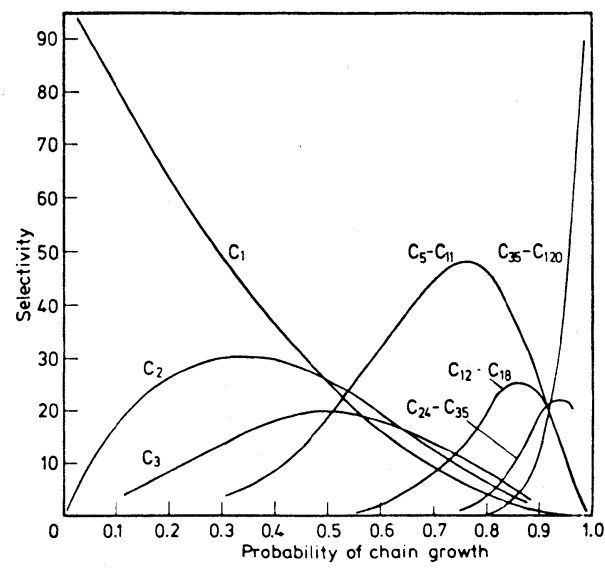

Fig. 2 Plots of various selectivities (percent carbon atom basis), The highest $\mathrm{C}$ number was arbitrarily taken to be 120 . 
成できない。一方，メタン ${ }^{8)}$ とメタノール合成 ${ }^{9)}$ では高 選択性の合成法がすでに確立されており, 現在多くの研 究者によりオレフィン，ガソリン成分またはジーゼル油 成分の高選択性合成法の開発が精力的に進められてい る5)。すなわち Schulz-Flory 則に従わない合成法であ る。生成物からみた選択性制御の視点は, 表 1 に示すよ 5に生成物因子, 触媒因子, 反応条件因子の 3 つに大別 される。

炭化水素合成では。燃料製造として $\mathrm{SNG}\left(\mathrm{C}_{1} \sim \mathrm{C}_{4}\right)$, ガソリン $\left(\mathrm{C}_{5} \sim \mathrm{C}_{11}\right)$, ジーゼル油 $\left(\mathrm{C}_{9} \sim \mathrm{C}_{25}\right)$ などがあり,

Table 1 Factors of product control of carbon monoxide hydrogenation.

I. Product Factor

1. Hydrocarbon

a. Polymerization $\cdots$ chain growth, SchulzFlory distribution rule

b. Double bond (olefin) and its position

c. Cyclization and aromatization

d. Branching ( $\mathrm{n} /$ iso ratio)

e. Removal of oxygen $\left(\mathrm{CO}_{2}\right.$ or $\left.\mathrm{H}_{2} \mathrm{O}\right) \ldots$ disproportionation ( $2 \mathrm{CO} \rightarrow \mathrm{CO}_{2}+\mathrm{C}$ ), hydrogen activity $\left(\mathrm{H}_{2} \mathrm{O}\right.$ formation)

2. Oxygenated compounds

a. Methanol

b. $\mathrm{C}_{2}$-oxygenated compounds (glycol, ethanol, acetic acid, etc )

II. Catalyst Factor

1. Metal-.group VIII metals and other metals

2. Alloy $\cdots$ ensemble effect, ligand effect

3. Additive...alkali metal, alkaline earth metal, halogen, phosphorus

4. Support

a. Chemical factor $\cdots$ surface property (acidbase), immobilization (SMSI effect.)

b. Physical factor...surface area, pore size, bulk property

5. Particle size of supported metal

6. Poisoning...coke formation, sulfur deposit

7. Sintering

III. Reaction Factor

1. Temperature

2. Pressure

3. $\mathrm{CO} / \mathrm{H}_{2}$ ratio

4. Space velocity

5. Reactor-..fixed-bed, fluidized-bed

6. Additive effect (methanol, ethylene, etc.)
化学原料としてェチレン, プロピレン，ブテン類などの 低級オレフィンがある。Schulz-Flory 則に従わない新 しい触媒開発が試みられている。 $\mathrm{C}_{2}$ 以上の含酸素化合 物の一酸化炭素と水素からの直接合成は, Rh 系の触媒 ${ }^{3}$, 10 13), 複合酸化物系の触媒 ${ }^{4)}$ があり, 反応条件の穏和化, 目標生成物の収率向上, 触媒の再生などに大変苦労して いる。

$\mathrm{C}_{1}$ 化学の新しいプロセスとして, 表 2,3 に示すよ うに, 次のように整理できる。

（1）従来の合成ガスからの直接方法

(2) 合成ガスから合成されるメタノールからの合成 （ex.メタノールからガソリン合成）もしくは合成ガス ナメタノール系からの合成（ex. ホモロゲーションによ るエタノール合成）などの間接方法

（3）第 3 物質十合成ガスもしくは第 3 物質十メタノ 一ル系からの合成による間接方法

高価な触媒を用いて苛酷な反応条件で目標物質を直接 合成ガスから入手するプロセスが, 必ずしも好ましいと

Table 2 Fuels and chemicals derived from synthesis gas and methanol

\begin{tabular}{c|l|l}
\hline Feedstock & \multicolumn{1}{|c}{ Fuels } & \multicolumn{1}{c}{ Chemicals } \\
\hline $\mathrm{CO}+\mathrm{H}_{2}$ & $\begin{array}{l}\text { Gasoline, SNG, } \\
\text { Diesel fuel, } \\
\text { Fuel oil, } \\
\text { Alcohol fuels }\end{array}$ & $\begin{array}{l}\text { Ethylene glycol } \\
\text { Acetic acid, Ethanol, } \\
\text { Dimethyl ether, } \\
\text { Polyethylene }\end{array}$ \\
\hline $\mathrm{CH}_{3} \mathrm{OH}$ & Gasoline & $\begin{array}{l}\text { Lower olefins, BTX, } \\
\text { Methyl formate, } \\
\text { Formaldehyde }\end{array}$ \\
\hline $\mathrm{CH}_{3} \mathrm{OH}$ & Alcohol fuels & $\begin{array}{l}\text { Acetic acid, Ethanol, } \\
\text { Acetaldehyde, } \\
\text { Acetic anhydride, } \\
\text { Methyl acetate, } \\
\text { Ethyl acetate, } \\
\text { Ethylene glycol }\end{array}$ \\
\hline
\end{tabular}

Table 3 Additives effect on reactions $\mathrm{CO}+\mathrm{H}_{2}$ or $\mathrm{CH}_{3} \mathrm{OH}$.

\begin{tabular}{l|l}
\hline Additives & \multicolumn{1}{|c}{ Chemicals } \\
\hline Alcohols & Carboxylic acids, Higher alcohols \\
\hline Olefins & $\begin{array}{l}\text { Alcohols, Aldehydes, Ketones, } \\
\text { Carboxylic acids }\end{array}$ \\
\hline Ammonia & Nitriles, Amines, Isocyanates, Urethanes \\
\hline Aromatics & Styrene \\
\hline
\end{tabular}




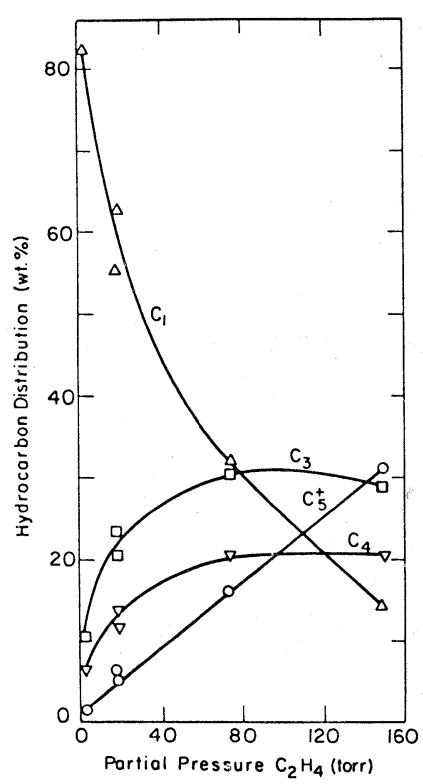

Fig. 3 Product distribution for fixed reaction conditions ( $6 \mathrm{~atm}, 3: 1 \mathrm{H}_{2}: \mathrm{CO}, 300{ }^{\circ} \mathrm{C}$ ) as a function of added ethylene.

は限らない。また，直接方法でも微量の第 3 物質を入れ ることにより，同一反応条件下で生成物分布に大きなシ フトが見出されている(図3 $)^{14,15)}$ 。

\section{2. 炭化水素合成における選択性制御}

目標生成物が決まったら，選択性を変える因子として 触媒と反応条件がある。直接合成による炭化水素合成 は, ここ数年表 1 の I-1 に示すように各因子がかなり明 確になってきた。さらに 1978 年ごろから一酸化炭素の活 性化, 中間体の構造, 連鎖成長機構について激しい論争 が展開され，有機金属化学者より提案されていた中間体 および $\mathrm{CO}$ 挿入反応による重合機構の説に大きな疑問が 投げかけられ吕) Joyner らによる CO 解離説 ${ }^{17)}$ 抢よび Pettit らによる $\mathrm{CH}_{2}$ 連鎖成長機構により Fischer-Tropsch 反応の機構が解明されつつある ${ }^{18,19)}$ 。選択性の良 い触媒開発には反応機構の理解が非常に重要なので, 最 近提案された反応機構について後に詳しく触れたい。

Schulz-Flory 則に従 5 Fischer-Tropsch 合成は生成 物分布が広い範囲にわたるため不経済なので, 単一生成 物の高選択的合成法として次のような方法が現在考えら れている5,20)。

（1）細孔径で連鎖成長を制御

$\mathrm{Co}-\mathrm{A}, \mathrm{Co}-\mathrm{Y}, \mathrm{Ru}-\mathrm{Y}$ 触媒は $\mathrm{C}_{8}$ 以上の生成物が極め て少ない21 24)。
Table 4 Product distribution of carbon monoxide hydrogenation by $\mathrm{Fe}-\mathrm{Mn}-$ $\mathrm{ZnO}-\mathrm{K}_{2} \mathrm{O}$ catalyst.

\begin{tabular}{l|r||l|r}
\hline \multicolumn{1}{c|}{ Product } & wt $\%$ & \multicolumn{1}{|c|}{ Product } & wt \% \\
\hline $\mathrm{CH}_{4}$ & 9.6 & $\mathrm{C}_{4} \mathrm{H}_{8}$ & 17.4 \\
$\mathrm{C}_{2} \mathrm{H}_{4}$ & 31.3 & $\mathrm{C}_{2}-\mathrm{C}_{4}$ paraffins & 15.7 \\
$\mathrm{C}_{3} \mathrm{H}_{6}$ & 22.2 & $\mathrm{C}_{5+}$ hydrocarbons & 3.8 \\
\hline
\end{tabular}

Catalyst : $100 \mathrm{Fe}: 100 \mathrm{Mn}: 10 \mathrm{ZnO}: 4 \mathrm{~K}_{2} \mathrm{O}$

Temperature : $320^{\circ} \mathrm{C}$

Pressure : $10 \mathrm{~atm}$

$\mathrm{CO} / \mathrm{H}_{2}$ ratio $: 1.0$

Space velocity : $500 \mathrm{~h}^{-1}$

Conversion : $86 \%$

（2）Schulz-Flory 重合を途中で遮断するために第 2 の触媒活性点を導入 ( 2 元機能触媒)

a. $\mathrm{CO}$ の水素化触媒+固体酸触媒(低級炭化水素) ${ }^{25}$, 26)

b. メタノール合成触媒 $+\mathrm{H}-\mathrm{ZSM}-5$ 触媒 ( $\mathrm{C}_{10}$ 以下の 炭化水素 $)^{25}$

（3） Fischer-Tropsch 触媒の修飾

$\mathrm{Fe}-\mathrm{Mn}-\mathrm{ZnO}-\mathrm{K}_{2} \mathrm{O}$ 触媒はメタン生成を抑えしかも低 重合 (表 4$)^{27)}$

（4） Fischer-Tropsch 重合プロセスによって選択 性を限定されない触媒の開発

a. Rh-クラスター系触媒によるエチレング リコール の合成

b. メタノール経由による方法 (ZSM-5 $)^{28)}$

メタノールを経由する方法で低級オレフィンの収率を 増すには，i） SVを大きくし，ii）表面酸性を弱く し29)，iii）大きなイオンを交換して pore size を小さ くし，iv）リン化合物もしくは $\mathrm{Sb}_{2} \mathrm{O}_{3}$ を加える ${ }^{30)} 。-$ 方，芳香族の収率を増すには，i） SVを小さくし，ii） 表面酸性を強くし，iii） $\mathrm{Zn}, \mathrm{Ni}, \mathrm{Re}$ をイオン交換する ${ }^{5)}$ 。

2. 1. 一酸化炭素の解離 一酸化炭素の水素化機構 として次の 6 つの反応ステップが触媒設計上重要となろ ${ }^{13)}$ 。

$\mathrm{CO}$ 解離の場合

(1) $\mathrm{C}-\mathrm{O}$ 結合の解離

(2) 解離した炭素上の $\mathrm{C}-\mathrm{H}$ 結合の生成

(3) C-C 結合の生成 (ex. $\mathrm{CH}_{2}$ の挿入)

$\mathrm{CO}$ 非解離の場合

（4）活性化水素による $\mathrm{O}-\mathrm{H}$ 結合の生成

（5）活性化水素による $\mathrm{C}-\mathrm{H}$ 結合の生成

(6) C-C 結合の生成 (ex. CO の挿入)

たとえばメタン合成では( 1 )と (2), Fischer-Tropsch 合成では（1），(2)，（3)，メタノール合成では（4） 
と（5)，グリコール合成では（4)，（5），（6 ）の反応 ステップを経由する。

一酸化炭素の吸着種としては Linear, Bridge 抢よび Face などの 1 点もしくは多点吸着種, Twin のような 1 個の金属原子に 2 分子以上の一酸化炭素が吸着する型

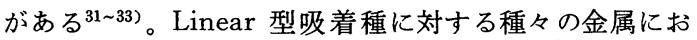
ける解離, 非解離の吸着条件は, $5 \sigma$ 軌道の供与と $2 \pi$ 軌 道への逆供与, $1 \pi$ 軌道の活性化の程度 ${ }^{34)}$, 化学吸着工 ネルギーの大小などにより整理されている $2,31,32,35)$ 。図 4 は $\mathrm{BEBO}$ 法により計算された $\mathrm{C}-\mathrm{O}$ 結合解離の活性 化エネルギーを示している ${ }^{36,37) 。 P d}, \mathrm{Pt}, \mathrm{Rh}$ などの白金 族金属に対しては解離の活性化エネルギーが大きく，分 子状吸着のみが存在する。室温における一酸化炭素の吸 着では Mo, Cr, Mn, Ti, V, W, Zr, Ni, Ta, Hf には解 離型吸着, $\mathrm{Pd}, \mathrm{Rh}, \mathrm{Pt}, \mathrm{Ru}, \mathrm{Ir}, \mathrm{Os}$ などの貴金属には安 定な分子状吸着, $\mathrm{Co}, \mathrm{Ni}, \mathrm{Tc}, \mathrm{Fe}, \mathrm{Re}$ などには原子状お よび分子状吸着種が存在するが，解離に要するエネルギ 一があまり大きくなく，温度上昇によって解離する ${ }^{37) 。 ~}$ 一般に周期律表 (長周期型) の左側にある金属元素ほど


離する。周期律表の右の方にある白金族金属は，吸着熱 が小さく解離もしにくい。さらに右側にある Ib 族の $\mathrm{Cu}$, $\mathrm{Ag}, \mathrm{Au}$ は吸着もしにくくなる。これは，周期律表の左 から右に行くに従い $\mathrm{d}$ バンドのエネルギーレベルが 3 $5 \mathrm{eV}$ 低くなるためと考えられている ${ }^{39)}$ 。の $\mathrm{d}$ バンド のエネルギーレベルが高い左の方にある金属ほど吸着分 子に対して電子を供与しやすく，金属と吸着分子間の電 子密度が増して吸着結合の強さが大きくなり，かつ $\mathrm{d}$ バ ンドから 2 原子分子の $2 \pi^{*}$ 軌道への電子供与も大きく なり解離しやすくなる。図4 の解離・非解離は室温の場

\begin{tabular}{|c|c|c|c|c|c|c|c|c|}
\hline III B & II B & $\bar{Z} \mathbf{B}$ & ZIB & III B & VIII & VIII & IIII & IB \\
\hline $\begin{array}{l}\mathrm{Sc} \\
-\end{array}$ & $\begin{array}{c}\mathrm{Ti} \\
\mathrm{D} \\
- \\
2.5\end{array}$ & $\begin{array}{l}v \\
- \\
- \\
1.7\end{array}$ & $\begin{array}{l}\mathrm{Cr} \\
- \\
- \\
4.2\end{array}$ & $\begin{array}{c}\text { Mn } \\
- \\
- \\
3.3\end{array}$ & $\begin{array}{c}\mathrm{Fe} \\
\mathrm{D} \\
3.5 \\
15.9\end{array}$ & $\begin{array}{c}\text { Co } \\
- \\
- \\
23.4\end{array}$ & $\begin{array}{c}\mathrm{Ni} \\
\mathrm{M} \\
3.08 \\
23.4\end{array}$ & $\begin{array}{l}\text { Cu } \\
- \\
- \\
-\end{array}$ \\
\hline $\begin{array}{l}\mathbf{Y} \\
-\end{array}$ & $\begin{array}{l}2 r \\
\overline{0} \\
\overline{0}\end{array}$ & $\begin{array}{c}\mathrm{Nb} \\
\overline{-} \\
\overline{0}\end{array}$ & $\begin{array}{c}\text { Mo } \\
0 \\
3.5 \\
5.8\end{array}$ & $\begin{array}{c}\text { Tc } \\
- \\
- \\
20.9\end{array}$ & $\begin{array}{r}\text { Ru } \\
\text { M } \\
3.15 \\
43.4\end{array}$ & $\begin{array}{c}\mathrm{Rh} \\
- \\
- \\
49.3\end{array}$ & $\begin{array}{c}P d \\
M \\
2.90 \\
58.5 \\
\end{array}$ & $\begin{array}{l}\text { Ag } \\
- \\
-\end{array}$ \\
\hline $\begin{array}{l}\text { Lo } \\
- \\
-\end{array}$ & $\begin{array}{c}\mathrm{Hf} \\
- \\
- \\
0\end{array}$ & $\begin{array}{l}\text { To } \\
- \\
\overline{0}\end{array}$ & $\begin{array}{c}W \\
D, M \\
3.2 \\
0\end{array}$ & $\begin{array}{c}\operatorname{Re} \\
- \\
- \\
15.9\end{array}$ & $\begin{array}{c}\text { Os } \\
- \\
- \\
36.7\end{array}$ & $\begin{array}{c}\mathrm{Ir} \\
\mathrm{M} \\
2.75 \\
41.8\end{array}$ & $\left\{\begin{array}{c}P 1 \\
M \\
2.60 \\
49.3\end{array}\right.$ & $\begin{array}{l}\text { Au } \\
-\end{array}$ \\
\hline
\end{tabular}

Fig. 4 The Periodic Table showing the room temperature adsorption behavior of $\mathrm{CO}$. $\mathrm{M}$ : molecular adsorption, $\mathrm{D}$ : dissociative adsorption. Energy separation: $\Delta(1 \pi-4 \sigma)$. Activation energy for dissociative chemisorption. (Bond Energy Bond Order calculations).
合で， Co, Ni, Ru 触媒は高温では解離優先だが，低温 では非解離吸着種になり水素化と競争して含酸素中間体 になろら ${ }^{40)}$ 。

表 5 に示すように，カーバイド $(\mathrm{M}-\mathrm{C})$ とオキサイド (M-O) の生·成エネルギーが大きいものほど安定化され, 解離しやすい。図 5，6，7 亿示すよ5に，解離の中間状 態执よびカーバイドのモデルとして考えられる鉄のクラ スター錯体の構造が決定されている ${ }^{41,42)}$ 。Fischer-Tropsch 反応の活性は, 解離後に生じるカーバイドとオキ
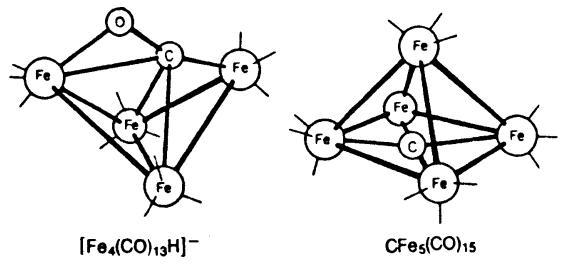

Fig. 5 Two cluster structures presented here are representative of various stages in the dissociative chemisorption of carbon monoxide on a metal surface.

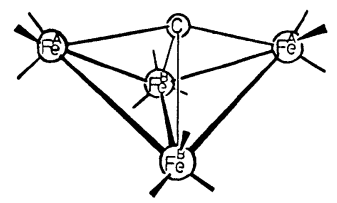

Fig. 6 The cluster structure presented is representative of carbon species after carbon monoxide dissociation.

Table 5 Dissociation energy $(D)$ of biatomic molecules ( $\mathrm{kcal} / \mathrm{mol})$.

\begin{tabular}{l|r|r|r|r}
\hline & $\begin{array}{r}\text { 3-dimensional } \\
\text { carbides known }\end{array}$ & Metal-C & Metal-O & $\Sigma D_{\mathrm{i}}$ \\
\hline & & & & $\mathrm{CO}: 256$ \\
$\mathrm{Pd}$ & - & $<110$ & 67 & 177 \\
$\mathrm{Ir}$ & - & 148 & 84 & 232 \\
$\mathrm{Pt}$ & - & 145 & 88 & 233 \\
$\mathrm{Rh}$ & - & 138 & 100 & 238 \\
$\mathrm{Ru}$ & - & 151 & - & $(251)$ \\
$\mathrm{Ni}$ & + & - & 99 & $(250)$ \\
\hline
\end{tabular}




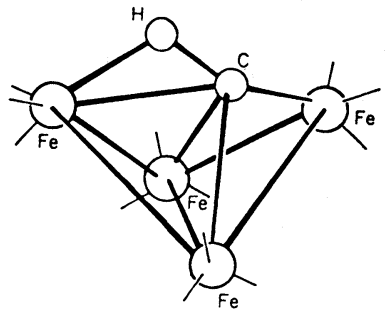

Fig. 7 The cluster structure presented is representative of intermediate state of $\mathrm{CH}$.

M. A. Beno, J. M. Williams, M. Tachikawa, E. L. Muetterties, $J$. Am. Chem. Soc., 103, 1485 (1981)

Table 6 Heat of formation of carbides and oxides.

\begin{tabular}{|c|c|c|c|c|}
\hline \multicolumn{4}{|c|}{$\Delta H_{\mathrm{f}}^{0}, \mathrm{kcal} / \mathrm{g}$-atom $\mathrm{C}$ or $\mathrm{O}$} & $\begin{array}{l}\text { Activity in } \\
\text { FT synthesis }\end{array}$ \\
\hline $\mathrm{Fe}_{2} \mathrm{C}$ & +5 & $\mathrm{Fe}_{2} \mathrm{O}_{3}$ & -68 & \multirow{3}{*}{ High } \\
\hline $\mathrm{Co}_{3} \mathrm{C}$ & +9.5 & $\mathrm{Co}_{3} \mathrm{O}_{4}$ & -48 & \\
\hline $\mathrm{NiC}$ & +11 & $\mathrm{NiO}$ & -58 & \\
\hline $\mathrm{TiC}$ & -54 & $\mathrm{TiO}_{2}$ & -109 & \multirow{2}{*}{ Low } \\
\hline $\mathrm{ZrC}$ & -45 & $\mathrm{ZrO}_{2}$ & -129 & \\
\hline $\mathrm{Mo}_{2} \mathrm{C}$ & +4.3 & $\mathrm{MoO}_{3}$ & -60 & Medium \\
\hline WC & -10 & $\mathrm{WO}_{3}$ & -67 & (expected) \\
\hline
\end{tabular}

サイドの生成熱から予測できる。表 6 に示すように，力 ーバイドと酸化物の生成エンタルピーが大きく安定化し すぎる $\mathrm{Ti}, \mathrm{Zr}$ での反応活性は小さい43)。

解離後の水素化はメタンの場合 $\mathrm{C} \rightarrow \mathrm{CH} \rightarrow \mathrm{CH}_{2} \rightarrow$ $\mathrm{CH}_{3} \rightarrow \mathrm{CH}_{4}$ と進む。有機金属化合物でも図 6,7,8に 示すように対応するものが知られているが，錯体でのこ の一連の水素化反応の活性化エネルギーは小さい13)。 $\mathrm{M}_{1}-\mathrm{C}, \mathrm{M}_{\mathrm{m}}-\mathrm{CH}, \mathrm{M}_{\mathrm{n}}-\mathrm{CH}_{2}$ の $1, \mathrm{~m}, \mathrm{n}$ の值が小さい(金 属-炭素の不飽和度が高い) ほど反応性が高い13)。C-C 結合の生成は表面カーバイドの状態で連鎖成長し, C-C 結合生成（一種のグラファイト）後の水素化による炭化 水素の生成は生成物分布拉よび水素化速度の視点から無

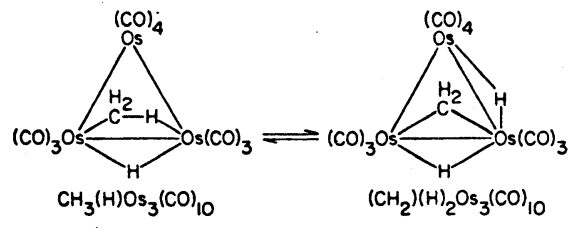

Fig. 8 This is a representation of the remarkable equilibrium solution of two cluster molecules, one a methylene and the other a methyl species, which rapidly interconvert.
理であろう。部分水素化した炭化水素の中間体 $\left(\mathrm{M}_{3} \mathrm{CH}\right.$, $\mathrm{M}_{2} \mathrm{CH}_{2}, \mathrm{MCH}_{3}$ ) は非常に速く平衡に達するので, この 中間体による C-C 結合生成が最も可能性が高い $\left.{ }^{13}, 35\right) 。$ 特に $\mathrm{CH}_{2}$ 吸着種が Fischer-Tropsch 反応で最も重要 である ${ }^{18,19) 。 ~}$

\section{2. 炭化水素合成における C-C 結合の生成}

Pettit らは (a) 一酸化炭素十水素の原料ガス中にジア ゾメタン $\left(\mathrm{CH}_{2} \mathrm{~N}_{2}\right)$ を混合して反応を行った場合におけ る炭化水素の生成物分布と, ジアジメタンを混合しない 場合との変化を調べ，さらに ( b ) ${ }^{13} \mathrm{CO}+\mathrm{H}_{2}+{ }^{12} \mathrm{CH}_{2} \mathrm{~N}_{2}$ （種々のジアゾメタン混合比で行った）反応を行い， ${ }^{13} \mathrm{C}$ と ${ }^{12} \mathrm{C}$ の生成物分布を調べて図 9 に示す 3 つの代表的な 反応機構, Fischer-Tropsch(カーバイド説), Anderson-

1. Fischer-Tropsch mechanism Polymerization of $\mathrm{CH}_{2}$ fragments

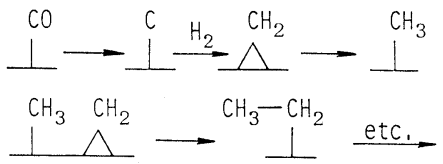

2. Anderson-Emmett mechanism

Condensation of $\mathrm{H}_{2} \mathrm{O}$ loss between hydroxymethylene groups

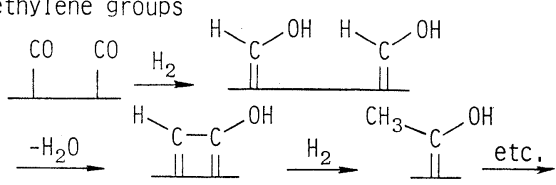

3. Pichler-Schultz mechanism

Insertion of $\mathrm{CO}$ into a metal-alkyl bond

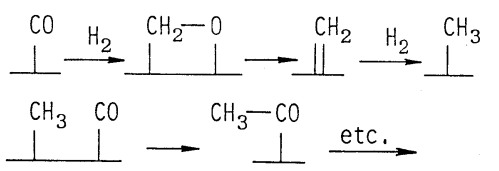

Fig. 9 Chain growth mechanism of carbon monoxide hydrogenation.

Table 7 Product distribution of propylene by proposal mechanisms.

\begin{tabular}{c|c|c}
\hline $\begin{array}{c}\text { Proposal } \\
\text { mechanism }\end{array}$ & $\begin{array}{c}\text { Product } \\
\text { distribution }\end{array}$ & $\begin{array}{c}\text { Propylene } \\
\left(\mathrm{CH}_{3}-\mathrm{CH}=\mathrm{CH}_{2}\right)\end{array}$ \\
\hline $\begin{array}{c}\text { Pichler }- \\
\text { Schultz }\end{array}$ & no change & ${ }^{12} \mathrm{C}-{ }^{13} \mathrm{C}-{ }^{13} \mathrm{C}$, \\
\hline $\begin{array}{c}\text { Fischer- } \\
\text { Tropsch }\end{array}$ & higher shift & ${ }^{13} \mathrm{C}-{ }^{13} \mathrm{C}-{ }^{13} \mathrm{C}$ \\
\hline $\begin{array}{c}\text { Anderson- } \\
\text { Emmett }\end{array}$ & bimodal $\mathrm{C}$ mixture \\
\hline
\end{tabular}


Emmett (脱水縮合説), Pichler-Schultz (CO 挿入説) 機構を比較検討した ${ }^{19)}$ 。これらの反応機構を ${ }^{13} \mathrm{CO}+\mathrm{H}_{2}$ $+{ }^{12} \mathrm{CH}_{2} \mathrm{~N}_{2}$ の反応における生成物分布と 1 生成物である プロピレン中の ${ }^{13} \mathrm{C}$ と ${ }^{12} \mathrm{C}$ の分布を予測して整理したの が表 7 である。もしも Pichler-Schultz 機構で進行す る.とすれば, この機構は $\mathrm{CO}$ 挿入のみで連鎖成長する ので（a）の生成物分布は変わらず, (b)のプロピレンの ${ }^{13} \mathrm{C}$ と ${ }^{12} \mathrm{C}$ の分布は ${ }^{12} \mathrm{C}-{ }^{13} \mathrm{C}-{ }^{13} \mathrm{C},{ }^{13} \mathrm{C}-{ }^{13} \mathrm{C}-{ }^{13} \mathrm{C}$ になる。

図 10に示すよ5に実験結果の生成物分布は高炭素数側 ヘシフトし, またプロピレンの ${ }^{13} \mathrm{C}$ と ${ }^{12} \mathrm{C}$ の混合比は, 図11に示すように Fischer-Tropsch 機構で進行する

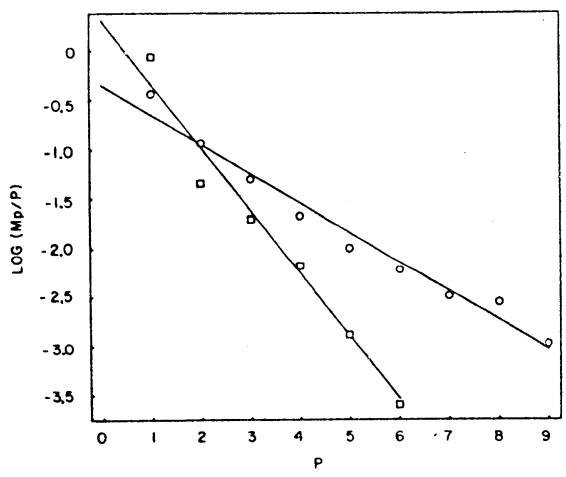

Fig. 10 Plots of $\log \left(\mathrm{M}_{\mathrm{p}} / \mathrm{P}\right)$ vs. $\mathrm{P}$ for the distribution of oligomers produced when $\mathrm{CO}$ and $\mathrm{H}_{2}(\square)$ and $\mathrm{CO}+\mathrm{H}_{2}+\mathrm{CH}_{2} \mathrm{~N}_{2}(\mathrm{O})$ are passed over a cobalt catalyst.

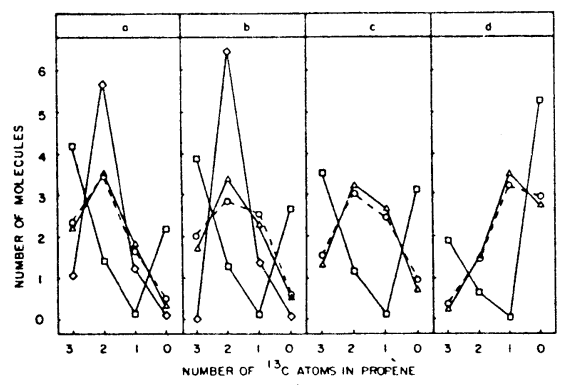

Fig. 11 Distribution of the isotopically labeled propene molecules produced upon passage of mixtures of $90 \%{ }^{13} \mathrm{CO}+10 \%{ }^{12} \mathrm{CO}, \mathrm{H}_{2}$. and ${ }^{12} \mathrm{CH}_{2} \mathrm{~N}_{2}$ over a cobalt catalyst. The experimentally observed distribution is given by the points joined via the dotted line. The distributions predicted by the Pichler-Schultz mechanism are given by the symbol $\diamond$, that predicted by the AndersonEmmett mechanism by the symbol $\square$, and that predicted by the Fischer-Tropsch scheme are given by the symbol $\triangle$.
と仮定したものとほぼ一致する。またコバルト/けいそ5 土触媒で $1 \mathrm{~atm}, 210{ }^{\circ} \mathrm{C}$ でのジアゾメタン反応と一酸化 炭素十水素反応の $\mathrm{C}_{4}$ の生成物分布は酷似している（図 $12)^{18)}$ 。さらに $\mathrm{Ni}, \mathrm{Pd}, \mathrm{Fe}, \mathrm{Co}, \mathrm{Ru}, \mathrm{Cu}$ 触媒ではジア ゾメタンからエチレンを生成するが，図 13 に示すよう に，水素の存在下ではこの反応は大きく変わる。すなわ ち $\mathrm{Ni}, \mathrm{Pd}, \mathrm{Fe}, \mathrm{Co}, \mathrm{Ru}$ 触媒ではジアゾメタン十水素か ら $\alpha$-オレフィンと $n$-パラフィンを生成する。特に $\mathrm{Pd}$, $\mathrm{Ni}$ 触媒ではメタン生成が多い。Co, Fe, Ru 触媒では, $\alpha$ ーオレフィンと $n$-パラフィンの生成物分布は FischerTropsch 反応と同じょうに反応温度と水素分圧に依存 する。水素分圧を増すと，オレフィン生成と連鎖成長は 減少する。 $\mathrm{Cu}$ 触媒ではジアゾメタン十水素でもエチレ

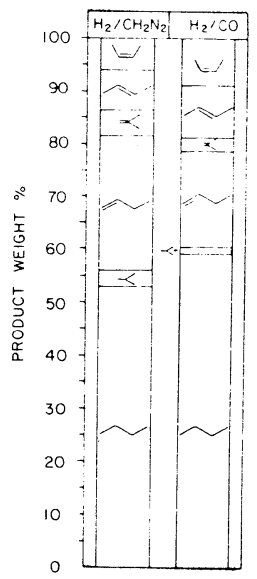

Fig. 12 Comparison of four-carbon isomer distributions obtained with $\mathrm{H}_{2} / \mathrm{CH}_{2} \mathrm{~N}_{2}$ and $\mathrm{H}_{2} /$ $\mathrm{CO}$ over a $39 \% \mathrm{Co} /$ kieselguhr catalyst at $210^{\circ} \mathrm{C}$ and 1 -atmosphere pressure.

1. $\mathrm{CH}_{2} \mathrm{~N}_{2} \ldots \ldots \mathrm{Ni}, \mathrm{Pd}, \mathrm{Fe}, \mathrm{CO}, \mathrm{Ru}, \mathrm{Cu}$

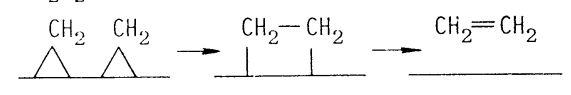

2. $\mathrm{CH}_{2} \mathrm{~N}_{2}+\mathrm{H}_{2} \ldots \ldots \mathrm{Ni}, \mathrm{Pd}, \mathrm{Fe}, \mathrm{CO}, \mathrm{Ru}$

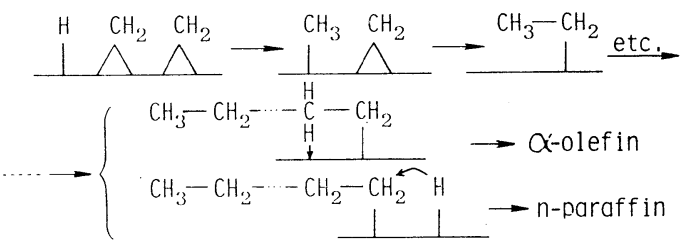

3. $\mathrm{CH}_{2} \mathrm{~N}_{2}+\mathrm{H}_{2}, \ldots . \mathrm{Cu}$ (no activation of $\mathrm{H}_{2}$ )

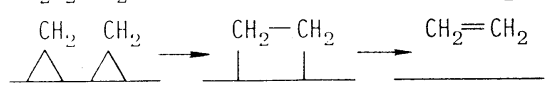

Fig. 13 Mechanisms on polymerization of diazomethane over various metal catalysts. 
ンしか生成しない。すなわち $\mathrm{Cu}$ 触媒の場合は水素活性 がなく, 最初のステップにおいて $\mathrm{CH}_{3}$ が生成しないと 表面に多数の $\mathrm{CH}_{2}$ 吸着種があっても次々と重合しない ことがわかる。最後にメタル上のアルキル基が脱離する 際に, 表面上のHと反応してパラフィンを生成するか, あるいはアルキル基から $\beta$-hydride引き抜きにより $\alpha$ オレフィンを生成する ${ }^{18)}$ 。

\section{3. 含酸素中間体と選択性制御}

$\mathrm{CO}$ 非解離の場合は，反応ステップの中で水素の活性 化が最重要となる。分子状水素 (dihydrogen) が吸着 $\mathrm{CO}$ やカルボニル錯体の $\mathrm{CO}$ と直接に反応するとは考え られないので，解離した水素がどのような状熊に活性化 されているか，すなわちヒドリド $\left(\mathrm{H}^{-}\right)$, プロトン $\left(\mathrm{H}^{+}\right)$, 水素ラジカル $(\mathrm{H} \cdot)$ のいずれの状態にあるかである。 $\mathrm{CO}$ の非解離吸着種 $\left(\mathrm{M}-\mathrm{C}^{+\delta}-\mathrm{O}^{-\delta}\right)$ は解離水素の状態に より 2 種類の反応中間体を与える。非解離 $\mathrm{CO}$ の炭素原 子は求核試薬と反応し, 一方酸素原子はルイス塩基とし て働き求電子試薬と反応する1)。すなわちヒドリディッ クな水素 $\left(\mathrm{H}^{-\delta}\right)$ は $\mathrm{M}-\mathrm{CO}+\mathrm{M}-\mathrm{H}^{-\delta} \rightarrow \mathrm{M}-\mathrm{CHO}+\mathrm{M}$ の 反応式で示されるように formyl 中間体を与え，一方プ ロトニックな水素 $\left(\mathrm{H}^{+\delta}\right)$ は $\mathrm{M}-\mathrm{CO}+\mathrm{M}-\mathrm{H}^{+\delta} \rightarrow \mathrm{M} \equiv \mathrm{C}-$ $\mathrm{OH}+\mathrm{M}$ の反応式で示されるように alcoholic 中間体を 与える ${ }^{44)}$ 。特に $\mathrm{Zr}, \mathrm{Ti}$ やアクチニド金属のような $\mathrm{d}$ 電 子不足な金属は $\mathrm{M}-\mathrm{CHO}$ 間に $\pi$ 性の結合を生じる formyl 構造も alcohol 構造も水素原子と反応して共に $\mathrm{M}=\mathrm{CHOH}$ にな $り$,さらに水素原子と反応して $\mathrm{M}-\mathrm{CH}_{2}$ $\mathrm{OH}$ となると考えられる ${ }^{45)}$ 。

固体表面上（金属もしくは金属イオン上）で活性化さ れたプロトニックな水素は，前述したよ5に分子状吸着 した $\mathrm{CO}$ の酸素原子と相互作用を起こし， O-H 結合を 生成する ${ }^{13)}$ 。すなわち, 金属から吸着 $\mathrm{CO}$ の炭素原子人 の電子供与 (back donation) が大きいと, C-O 結合が 弱まり酸素は弱い塩基性になるので, 触媒表面の $\mathrm{L}$ 酸点 と相互作用を起こし酸素は水素化されやすくなり， O-H 結合が生成する ${ }^{46,47) 。}$

分子状吸着 $\mathrm{CO}$ 亿対する $\mathrm{C}-\mathrm{H}$ 結合の生成は, ${ }^{\mathrm{H}}{ }_{\mathrm{M}}$

$\mathrm{C} \equiv \mathrm{O} \rightarrow \mathrm{M}-\mathrm{C} \leqslant \mathrm{O}$ (metal formyl 中間体) が考えられ ている。この反応は錯体化学反応では未だ見つかってい ないが, $\mathrm{M}(\mathrm{CO})_{\mathrm{x}} \mathrm{L}_{\mathrm{y}}$ に $\mathrm{BR}_{3} \mathrm{H}^{-}$(強い還元試薬) が反応 することにより $\mathrm{M}-\mathrm{C} \leqslant \mathrm{H}$ 其 が生成する例はある（図 $14)^{48)}$ 。このように ホルミル錯体の合成には $\mathrm{H}^{-}$の移

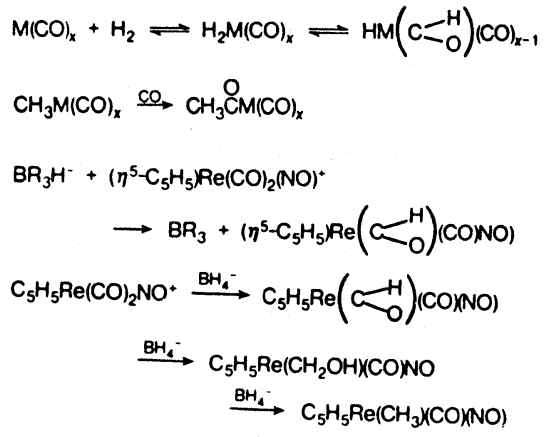

Fig. 14 Metal formyl formation and its reaction.

動が必要である。 $\mathrm{ZnO}$ 触媒の $\mathrm{Zn}-\mathrm{H}$ の $\mathrm{H}$ は強いヒドリ ドイオンである ${ }^{13,49)}$ 。メタノールおよび $\mathrm{C}_{2}$ 含酸素生成 物合成の中間体として metal formyl が提案されてい $3^{50)}$ 。

メタノール合成触媒である $\mathrm{Cu} / \mathrm{ZnO} / \mathrm{Al}_{2} \mathrm{O}_{3}$ または $\mathrm{Cu} /$ $\mathrm{ZnO} / \mathrm{Cr}_{2} \mathrm{O}_{3}$ の複合酸化物触媒では, $\mathrm{ZnO}$ マトリックス 中に銅は $\mathrm{Cu}(\mathrm{I})$ の状態で固溶している ${ }^{50)}$ 。一酸化炭素 は $\mathrm{Cu}(0)$ には吸着しないが， $\mathrm{Cu}(\mathrm{I})$ には吸着し活性 化される ${ }^{51)}$ 。タタールの合成機構としては，Cu (I)$\mathrm{CO}$ K $\mathrm{Zn}-\mathrm{H}^{-}$の $\mathrm{H}^{-}$が反応して生じる $\mathrm{Cu}(\mathrm{I})-\mathrm{C} \leqslant \mathrm{O}$ 中間体経由が提案されている。 $\mathrm{ZnO}$ 触媒上で反応ガス として ${ }^{13} \mathrm{C}^{16} \mathrm{O}+{ }^{12} \mathrm{C}^{18} \mathrm{O}+\mathrm{H}_{2}$ を用いメタノールを合成し たところ， ${ }^{13} \mathrm{CH}_{3}{ }^{18} \mathrm{OH}$ は生成しなかった ${ }^{52)}$ 。この事実は， メタノール合成中に $\mathrm{CO}$ 解離反応を含まないことを示唆 している。また $\mathrm{D}_{2}$ を用いて Isotope 効果を調べたとこ ろ，水素の解離が律速であることがわかった ${ }^{53)}$ 。CO が 解離しにくい Ir, Pd, Pt 触媒では, メタノール合成条件 で $\mathrm{ZnO}$ なしでもメタノールが合成される ${ }^{54)}$ 。

formyl 中間体の次に金属が electropositive ならホル ミル基の酸素も金属と結合して $\mathrm{O} \underset{\mathrm{M} \succ}{-}-\frac{\mathrm{C}}{-\mathrm{H}}$ （ホ ルムアルデヒド錯体の例：図 15）を生じ55, さらにこれ

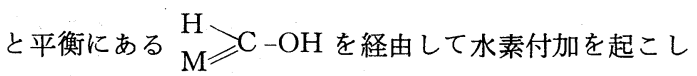
$\mathrm{H}$

$\mathrm{H}-\stackrel{\mathrm{C}}{\mathrm{C}}-\mathrm{OH}$ を生じ, 最後にメタノールが合成されると考 $\mathrm{M}$

えられる13)。

ヒドロホルミル化反応の結果より,アルキル基が大きく なるほど CO の挿入反応は急速に遅くなる ${ }^{56)}$ 。したがっ て低級炭化水素では可能かもしれないが，大きな炭化水 素合成における CO 挿入-水素化の繰り返しによる連鎖 


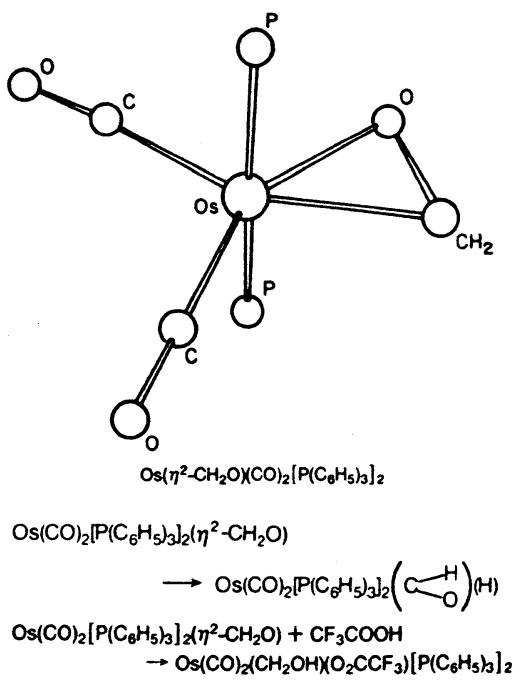

Fig. 15 The skeletal array of atoms in the coordination sphere of a formaldehyde complex, Os $\left(\eta^{2}-\mathrm{CH}_{2} \mathrm{O}\right)(\mathrm{CO})_{2}\left[\mathrm{P}\left(\mathrm{C}_{6} \mathrm{H}_{5}\right)_{3}\right]_{2}$, and its reaction to form $-\mathrm{CHO}$ or $-\mathrm{CH}_{2} \mathrm{OH}$ complex.

成長は, アルキル基への $\mathrm{CO}$ 挿入反応とアルキル基の水 素化反応が競争反応となるから，速度の小さい $\mathrm{CO}$ 挿入 反応経由は無理であろ ${ }^{13)}$ 。

$\mathrm{Rh}$ クラスターを塩基性酸化物に担持した触媒を用い ると, 合成ガスからエタノールが生成する3゙。ロジウム 上で一酸化炭素は解離して水素化し, メチル基が生成す る。ロジゥムの粒子サイズが小さいので $\mathrm{CH}_{2}$ の濃度は 少なく, $\mathrm{CH}_{3}$ に対する挿入は一酸化炭素が優先される。 $\mathrm{CO}$ 挿入後水素化し，エタノールを与えると考えられる。 ロジウム自身は $200{ }^{\circ} \mathrm{C}$ 以下では $\mathrm{CO}$ を解離しにくいので, 塩基性担体 (電子供与性) は $\mathrm{CO}$ 解離を助ける役割と $\mathrm{H}^{-}\left(\mathrm{CH}_{3} \mathrm{CO}\right.$ の $\mathrm{H}$ 付加)サイトの両方の作用を持ってい ると思われる。 $\mathrm{Rh}-\mathrm{CH}_{3}$ への $\mathrm{CO}$ 挿入は比較的速い。

\section{4. 水素の活性化}

水素の吸着および活性化に関する研究例は，一酸化炭 素に比べて非常に少ない。金属上で水素分子は解離の活 性化エネルギーが小さいので, 一酸化炭素と異なり分子 状吸着は低温を除いては不可能で, 室温以上では必ず解 離吸着し ${ }^{36,37)}$, on-top 型と bridge 型をとる ${ }^{57,58)}$ 。被 覆率 $\theta$ が小さいときは on-top 型, $\theta$ が増すと bridge 型が現われる ${ }^{57)}$ 。水素の吸着は一酸化炭素に強く阻害さ れ，タングステン上では $\theta_{\mathrm{Co}}<0.5$ にならないと吸着しな $\left(^{57)}\right.$ 。

遷移金属表面上では金属から水素人電子が移行し, 解 離吸着した水素原子はヒドリド的になる。担持金属触媒
上の水素の性質を考えるときには，酸化物担体の問題が ある。金属上で解離吸着したヒドリド的な水素が担体上 に移動する ${ }^{59)}$ 。これはスピルオーバーと呼ばれているが, この現象の説明は難しい60)。 $\mathrm{Pt}-\mathrm{Al}_{2} \mathrm{O}_{3}$ および $\mathrm{Ni}-\mathrm{Al}_{2} \mathrm{O}_{3}$ 触媒が良く議論されているが，ヒドリド的な水素が担体 上に移りプロトンに変わる(1)。この $\mathrm{H}^{-}$から $\mathrm{H}^{+}$への移 動をカリウムの添加により抑制する例も報告されてい る ${ }^{62)}$ 。一方，金属と担体の界面でそれぞれヒドリド的水 素とプロトニックな水素が再結合して水素分子を生じさ せる ${ }^{1)}$ 。酸化物担持金属触媒上の水素がどのような状態 であるか, $\mathrm{H}^{+}$と $\mathrm{H}^{-}$の濃度および強さが一酸化炭素の 水素化反応の活性・選択性に大きな影響を与えると推論 される。含酸素化合物合成の複合酸化物触媒での非解離 型分子状一酸化炭素吸着種にとり，ヒドリドの状態は活 性・選択性に対し極めて重要である。

表 8 に種々の水素に関する反応例と金属触媒との関係 を示したが58)，水素化される反応物の活性化状態とその

Table 8 Hydrogen activity on metal.

1. Hydrogen-deuterium exchange (Schuit et al.): $\mathrm{Pt}, \mathrm{Rh}, \mathrm{Ru}>\mathrm{Ni}, \mathrm{Co}>\mathrm{Fe}, \mathrm{Cu}$

2. Hydrogenation of ethylene (Beeck):

$\mathrm{Rh}>\mathrm{Pd}>\mathrm{Pt}>\mathrm{Ni}>\mathrm{Fe}>\mathrm{W}>\mathrm{Cr}>\mathrm{Ta}$

3. Hydrogenation of acetylene (Sheridan and Reid):

$\mathrm{Pd}>\mathrm{Pt}>\mathrm{Ni}, \mathrm{Rh}>\mathrm{Fe}, \mathrm{Cu}, \mathrm{Co}, \mathrm{Ir}>\mathrm{Ru}, \mathrm{Os}$

4. Hydrogenation of benzene (Schuit and Van Reijen):

$\mathrm{Pt}>\mathrm{Rh}>\mathrm{Ru}>\mathrm{Pd}>\mathrm{Co}>\mathrm{Ni}>\mathrm{Fe}$

5. Deuterium-ammonia exchange (Kemball):

$\mathrm{Pt}>\mathrm{Rh}>\mathrm{Pd}>\mathrm{Ni}>\mathrm{W}>\mathrm{Fe}>\mathrm{Cu}>\mathrm{Ag}$

6. Exchange of deuterium with most saturated hydrocarbons (Anderson):

$\mathrm{W}>\mathrm{Mo}>\mathrm{Ta}>\mathrm{Rh}>\mathrm{V}>\mathrm{Cr}>\mathrm{Zr}>\mathrm{Pt}>\mathrm{Pd}>\mathrm{Ni}$

$\mathrm{Co}>\mathrm{Fe}$

量および触媒の調製方法にも問題があるので，簡単に水 素化能の序列を結論できない。しかし，一般に第VII族金 属の水素化能は $\mathrm{Pt}, \mathrm{Pd}, \mathrm{Ni}$ が最も高く, ついで $\mathrm{Ir}, \mathrm{Rh}$, $\mathrm{Co}$ が高く, Ru, Fe は低い。一酸化炭素の解離・非解離 とこの水素化の両者とを考慮すると, 表 9 に示すように, $\mathrm{Ni}$ のように CO 解離しや寸く水素化能が高いとメタン, $\mathrm{Fe}, \mathrm{Ru}$ のように CO 解離しやすく水素化能が低いと高 級炭化水素, $\mathrm{Pd}$ のように $\mathrm{CO}$ 解離しにくく水素化能が 高いとメタノール合成, Rh のように中間の性質をもつ ものは $\mathrm{C}_{2}$ 含酸素化合物やヒドロホルミル化に好ましい 
Table 9 Hydrogenation of carbon monoxide over group VIII metal catalysts.

\begin{tabular}{l|l}
\hline $\mathrm{Ni}$ & Methanation \\
$\mathrm{Fe}, \mathrm{Co}$ & $\begin{array}{l}\text { Fischer-Tropsch synthesis, } \\
\text { Higher hydrocarbons, Higher alcohols }\end{array}$ \\
$\mathrm{Ru}$ & Chain growth (Polymethylene) \\
$\mathrm{Rh}$ & $\mathrm{C}_{2}$-Oxygenated compounds \\
$\mathrm{Pd}, \mathrm{Ir}, \mathrm{Pt}$ & Methanol synthesis \\
\hline
\end{tabular}

触媒となる ${ }^{63)}$ 。ロジウム代替触媒として最近複合酸化物 触媒の研究が盛んに行われるようになったが4)，メ夕， 一ル合成の際にも述べたように, 含酸素化合物の合成で は水素化能力, 特にヒドリド活性に注目する必要がある $5^{51)}$ 。図 16 は単独酸化物の $\mathrm{H}_{2}-\mathrm{D}_{2}$ 交換反応の速度定数

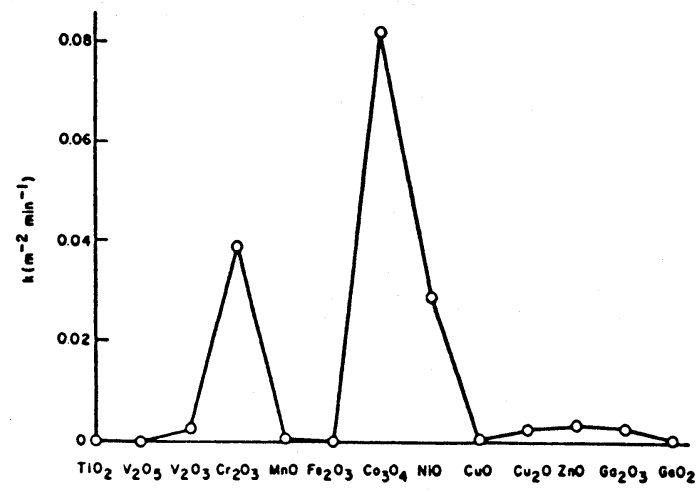

Fig. 16 First-order rate constants for $\mathrm{H}_{2}-\mathrm{D}_{2}$ exchange on various metal oxides.

の比較だが(64)，高い水素化活性をもつ $\mathrm{Cr}_{2} \mathrm{O}_{3}, \mathrm{Co}_{3} \mathrm{O}_{4}$, $\mathrm{NiO}, \mathrm{ZnO}$ は触媒設計するときに考慮されよう。IFP の 特許は一酸化炭素の水素化により主生成物としてエタ， ール, 副生成物としてメタノール,プロパノールを得 だ)。この触媒は $\mathrm{Cu}, \mathrm{Co}, \mathrm{Cr}$, 希土類, アルカリ, アル カリ土類の複合酸化物触媒であるが, $\mathrm{Co}, \mathrm{Cr}$ の酸化物 は水素活性の役割を担っていると考えられる。

\section{5. 触媒因子}

5. 1. 複合金属の触媒作用担持複合金属（合金, bimetal などの 2 種以上の金属) 触媒には, $\mathrm{Ru}-\mathrm{Cu}, \mathrm{Ni}-$ $\mathrm{Cu}$ のようなV兆族と $\mathrm{Ib}$ 族金属の組み合わせ, $\mathrm{Cu}-\mathrm{Au}$, $\mathrm{Ag}-\mathrm{Au}$ の上うな $\mathrm{Ib}$ 族金属同志を組み合わせて高分散 したものがある ${ }^{65,66)}$ 。複合することにより活性, 選択性 などの反応性が大きく変わる場合と, 担持状態, 分散状 態に変化をもたらし活性より寿命に著しい効果を現わす

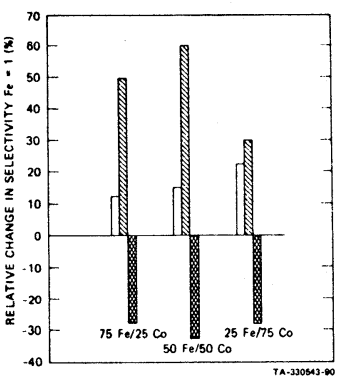

Fig. 17 Relative change in hydrocarbon selectivity exhibited by $\mathrm{Fe} / \mathrm{CO}$ catalysts relative to $\mathrm{Fe}$ at $523 \mathrm{~K}$ (Bulk alloy compositions in atom percent).

$\left(\square \mathrm{CH}_{4} ;\right.$; $\left.\mathrm{C}_{2}+\mathrm{C}_{3} ; \mathrm{C}_{4}{ }^{+}\right)$

場合がある ${ }^{67)}$ 。反応性の変わる場合も, 活性点の幾何学 的配置 (ensemble 効果, 金属触媒の活性点の集合) と 金属間の電子的相互作用 (ligand 効果) とに大別でき $3^{68)}$ 。

メタネーション反応用のニッケルに銅を添加した触媒 では, $\mathrm{CO}$ の解離は 2 個以上のニッケル金属(多点吸着) で起こり，銅には活性がないと考えられるので銅を添加 していくとニッヶルの ensemble が小さくなり, CO の 解離能が減少し触媒活性が低下する ${ }^{69}$ 。

一酸化炭素の水素化反応においてコバルトに鉄を添加 すると, 水素化能の高いコバルトの性質が鉄触媒により 抑えられ, メタンの生成が減り $\mathrm{C}_{2}, \mathrm{C}_{3}$ と $\mathrm{C}_{4}$ の炭化水 素生成の選択率が増大寸る（図 17）。鉄は合成ガスに 触れるとカーバイドや酸化物を表面に生成しやすく,こ のカーバイドの前の状態の吸着炭素は F-T 反応の中間 体と同じ吸着種と考えられるので, 水素化活性も高い。 一方コバルトはカーバイドや酸化物を生成しにくいが， F-T 反応活性も低い。鉄にコバルトを入れると，表面 の鉄の組成はバルクの鉄の組成より高いが鉄は還元しや

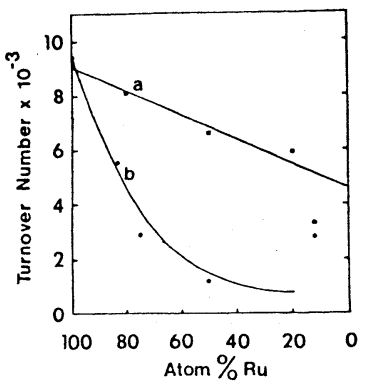

Fig. 18 Turnover number versus atom percent ruthenium in (a) ruthenium-nickel zeolites and (b) ruthenium-copper zeolites. 
すくなり，また $25 \%$ 以上コバルトが添加されるとカー バイド生成も防ぐ71)。 $3 \mathrm{H}_{2}+\mathrm{CO}$ の合成ガスではニッケ ル触媒上に炭化物を生成しにくいが, 鉄および $\mathrm{Fe}-\mathrm{Ni}$ 合 金は炭化物を生成する ${ }^{72)}$ 。

$\mathrm{Ru}-\mathrm{Y}$ ゼオライト触媒にニッケルを添加するとメタン 合成の turnover number は直線的に低下寸るが，銅を 入れると急激に低下寸る (図 18)。ルテニウムへのニッ ケルの添加は $\mathrm{CO}$ の解離活性を抑制し, 水素の解離活性 点を増大させる ${ }^{73)}$ 。一方，ルテニウムに少量の鉄を混合 すると表面は急激に鉄の濃度が上昇することが，2次イ オン質量分析 (SIMS) 測定の結果からわかった。図 19 に示すように表面の鉄の濃度が増すに伴ってメタンが減 り $\mathrm{C}_{2+}$ が増大し，かつ図20に示すようにオレフィンの 選択率が $100 \%$ 近くになる ${ }^{74)}$ 。合金触媒の場合，表面組 成がバルク組成に一致しないことは以前からよく言われ ていたが，SIMS による表面分析の結果から，どちらか 一方の金属の表面組成がバルク組成より高いことが多く

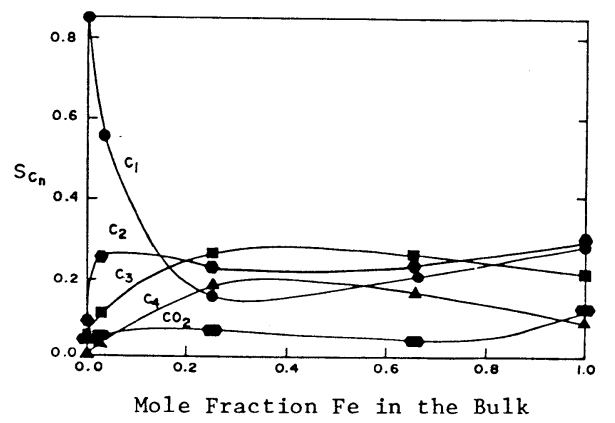

Fig. 19 Hydrocarbon selectvity in $3.3 \mathrm{H}_{2} / \mathrm{CO}$ at $1 \mathrm{~atm}$ and $573 \mathrm{~K}$ for freshly reduced FeRu catalysts as a function of bulk composition. $\mathrm{C}_{\mathrm{n}}$ indicates number of carbon atoms in the product molecule.

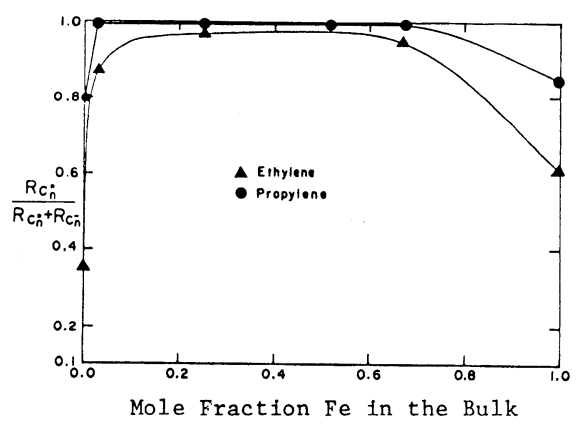

Fig. 20 Relative selectivity of FeRu catalysts to unsaturated products in $3.3 \mathrm{H}_{2} / \mathrm{CO}$ at 1 atm and $573 \mathrm{~K}$
の合金触媒に認められている。このように, SIMS 測定 は触媒作用の解明と触媒調製に極めて有効である。

5. 2. アルカリ金属の添加効果 Fischer-Tropsch 反応およびアンモニア合成には鉄触媒が使われており, 両者ともカリウム添加が反応に著しい効果を与える ${ }^{7,75}$, 76)。Fischer-Tropsch 反応に打ける鉄触媒へのカリウ ム添加効果は, カリウムが 1 電子放出し陽イオンになる とき鉄に電子供与するので鉄の電子密度が増加し, 吸着 $\mathrm{CO}$ への back donation を増大させる。したがって Fe$\mathrm{C}$ 結合を強化し $\mathrm{C}-\mathrm{O}$ 結合を弱めるので， $\mathrm{CO}$ の吸着熱 は増加し，CO の脱離を抑制し解離を促進させる。温度 を上げると表面上に吸着炭素を增やす ${ }^{77)}$ 。そこでパラフ インの選択率は減り，連鎖成長生成物およびオレフィン の選択率は増加する ${ }^{78)}$ 。特に低級オレフィンの選択率が 飛躍的に向上する（表 10）。一方，カリウムは鉄のシン タリングを起こさせ金属表面積を減少させるので，表面 積の大きいシリカもしくはアルミナ担体を用いて安定化 させる必要がある79)。しかし，あまり表面積が大きいと 鉄とカリウムが互いに孤立し，カリウムの効果が消失し てしま 578)。触媒の試薬として $\mathrm{K}_{\mathrm{x}} \mathrm{Fe}_{\mathrm{y}} \mathrm{L}_{\mathrm{z}}$ 錯体を使い, 調製段階ですでにカリウムと鉄が隣接し，しかも表面積 の大きい担体に高分散で担持させシンタリングを起こし にくくすると，単に $\mathrm{K}_{2} \mathrm{O}$ を担持して調製した $\mathrm{Fe}-\mathrm{K}_{2} \mathrm{O}$ $\mathrm{Al}_{2} \mathrm{O}_{3}$ 触媒と比較して $\mathrm{C}_{2} \sim \mathrm{C}_{5}$ オレフィン合成に対して

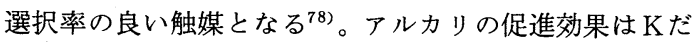
けでなく， $\mathrm{Li}, \mathrm{Na}, \mathrm{Rb}, \mathrm{Cs}$ にもある ${ }^{80)}$ 。原子番号が大き

Table 10 Effect of alkali addition on iron catalysts.

\begin{tabular}{c|c|c|c|c}
\hline Alkali & $\begin{array}{c}\text { Amount of } \\
\text { alkali } \\
\text { (relative } \\
\text { units)* }\end{array}$ & $\begin{array}{c}\text { Activity } \\
\text { CO+C } \\
\text { conversion } \\
(\%)\end{array}$ & $\begin{array}{c}\mathrm{CH}_{4} \\
\text { selectivity }\end{array}$ & \begin{tabular}{c}
$\mathrm{C}_{3} \mathrm{H}_{6}$ \\
\hline $\mathrm{C}_{3} \mathrm{H}_{8}$ \\
ratio
\end{tabular} \\
\hline & 0 & 63 & 41 & 0.2 \\
$\mathrm{~K}_{2} \mathrm{O}$ & 1.75 & 90 & 20 & 3 \\
& 2.1 & 90 & 15 & 5.7 \\
& 2.65 & 92 & 13 & 7.6 \\
& 3.4 & 94 & 12 & 11 \\
& 3.95 & 93 & 10 & 12 \\
\hline \multirow{5}{*}{$\mathrm{Na}_{2} \mathrm{O}$} & 0 & 63 & 41 & 0.2 \\
& 2.3 & 78 & 15 & 1.8 \\
& 4.5 & 85 & 13 & 2.3 \\
& 6.8 & 84 & 14 & 2.0 \\
& 9.1 & 87 & 16 & 1.7 \\
\hline
\end{tabular}

* Alkali levels all expressed on molar basis

**All selectivities, \% carbon atoin 
Table 11 Selectivity of ruthenium catalysts.

\begin{tabular}{|c|c|c|c|c|c|c|c|c|c|c|c|c|}
\hline \multirow{3}{*}{ Catalyst } & \multirow{3}{*}{$T(\mathrm{~K})$} & \multicolumn{11}{|c|}{$\mathrm{H}_{2} / \mathrm{CO}=3, P=101 \mathrm{kPa}$} \\
\hline & & \multirow{2}{*}{$\begin{array}{c}\mathrm{CO} \\
\text { conversion } \\
(\%)\end{array}$} & \multicolumn{9}{|c|}{ Product distribution (mole \%) } & \multirow{2}{*}{$\begin{array}{l}\mathrm{C}_{2+} / \mathrm{C}_{1} \\
\text { wt ratio }\end{array}$} \\
\hline & & & $\mathrm{C}_{1}$ & $\mathrm{C}_{2}=$ & $\mathrm{C}_{2}$ & $\mathrm{C}_{3}=$ & $\mathrm{C}_{3}$ & $\mathrm{C}_{4}=$ & $\mathrm{C}_{4}$ & $\mathrm{C}_{5}$ & $\mathrm{C}_{6}{ }^{+}$ & \\
\hline $2 \% \mathrm{Ru} / \mathrm{TiO}_{2}$ & 501 & 1.8 & 54 & 6 & 5 & \multicolumn{2}{|c|}{16} & 10 & & 5 & 4 & 2.7 \\
\hline $5 \% \mathrm{Ru} / \mathrm{Al}_{2} \mathrm{O}_{3}$ & 502 & 10.6 & 66 & 1 & 9 & \multicolumn{2}{|c|}{6} & 9 & & 6 & 4 & 1.8 \\
\hline $5 \% \mathrm{Ru} / \mathrm{SiO}_{2}$ & 492 & 7.1 & 72 & 0 & 9 & 2 & 3 & 0.3 & 7 & 7 & $<1$ & 1.3 \\
\hline $4 \% \mathrm{Ru} /$ Carbolac & 507 & 1.6 & 98 & 0 & 2 & 0 & 0 & 0 & 0 & 0 & 0 & 0.04 \\
\hline Unsupported $\mathrm{Ru}$ & 476 & 17.5 & 59 & $\operatorname{tr}$ & 9 & \multicolumn{2}{|c|}{10} & $<1$ & 6 & 6 & 9 & 2.5 \\
\hline
\end{tabular}

くなるにしたがいその効果は大きくなるが, ルビジウム， セシウムは価格がカリウムより高いので実際には使用さ れていない。もしもカリウムのような電子供与性物質が Fischer-Tropsch 反応を促進するのなら，硫黄のような 電子吸引性物質は同反応を阻害する。興味哚いことに, 硫黄は一酸化炭素の吸着解離反応に対してカリウムと全 く逆の作用を示す ${ }^{81)}$ 。

5. 3. 担体効果 ルテニウム触媒に対する担体効果 を調べたところ，表11に示すように活性は $\mathrm{Ru}-\mathrm{Al}_{2} \mathrm{O}_{3}$ $>\mathrm{Ru}-\mathrm{SiO}_{2}>\mathrm{Ru}-\mathrm{TiO}_{2}>\mathrm{Ru}$-活性炭の順で, メタンの選 択性は $\mathrm{Ru}$-活性炭 $>\mathrm{Ru}-\mathrm{SiO}_{2}>\mathrm{Ru}-\mathrm{Al}_{2} \mathrm{O}_{3}>\mathrm{Ru}-\mathrm{TiO}_{2}$, 連鎖成長の選択性はメタンの逆になる゙。すなわちチタニ ア担体の場合は水素の活性化が小さく, 最も連鎖成長が 進む ${ }^{82)}$ 。

一方ニッケル触媒に対する担体の効果については，電 顕観察の結果, $\mathrm{Ni}-\mathrm{SiO}_{2}$ と $\mathrm{Ni}-\mathrm{Al}_{2} \mathrm{O}_{3}$ は 3 次元粒子, $\mathrm{Ni}-\mathrm{TiO}_{2}$ は raft 構造の 2 次元粒子であり, 強い SMSI 効果を示すチタニア担体では水素の吸着が抑制される ${ }^{83)}$ 。 図 21 に示すように, $\mathrm{Ni}-\mathrm{SiO}_{2}$ および $\mathrm{Ni}-\mathrm{Al}_{2} \mathrm{O}_{3}$ 触媒で はニッケルの分散度が向上するほど一酸化炭素/水素の 吸着量比と $\mathrm{C}_{2+}$ 一の選択性は増加する。すなわち水素の 吸着に比べて一酸化炭素吸着が多い触媒ほど連鎖成長は

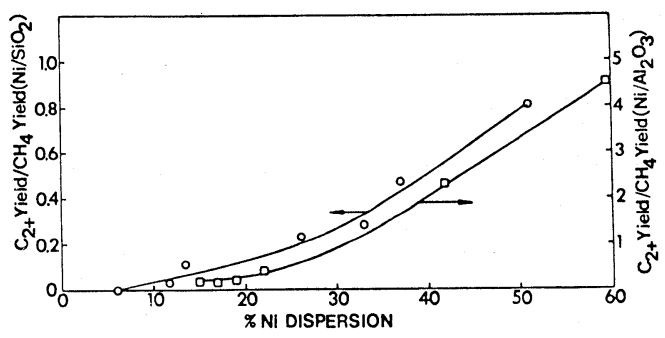

Fig. 21 Ratio of $\mathrm{C}_{2}$ hydrocarbon and methane yields versus percentage $\mathrm{Ni}$ dispersion: $\bigcirc \mathrm{Ni} / \mathrm{SiO}_{2}$ at $525 \mathrm{~K} ; \square \mathrm{Ni} / \mathrm{Al}_{2} \mathrm{O}_{3}$ at $500 \mathrm{~K}$.
進むことを示唆している ${ }^{84)}$ 。ニッケル金属と担体との相 互作用 (SMSI 効果) は $\mathrm{TiO}_{2}>\mathrm{Al}_{2} \mathrm{O}_{3}>\mathrm{SiO}_{2}$ の順に大 きく, 一酸化炭素/水素の吸着比もこの順に大きくなる。 活性および連鎖成長への選択性は $\mathrm{Ni}-\mathrm{TiO}_{2}>\mathrm{Ni}-\mathrm{Al}_{2} \mathrm{O}_{3}$ $>\mathrm{Ni}-\mathrm{SiO}_{2}$ である ${ }^{84)}$ 。また $\mathrm{Ni}-\mathrm{TiO}_{2}$ 触媒による連鎖成 長生成物中にはオレフィンよりもパラフィンの生成が多 く, 触媒上の炭素沈着による劣化も少なく, 金属粒子の シンタリングも起こりにく( ${ }^{85)}$ 。

SMSI 効果の大きい還元処理されたチタニア担体をア ルミナやシリカ担体と比較すると，前述したようにニッ ケルを担持した触媒では活性が増し，炭素数の大きいパ ラフィンへの選択性が増す。またルテニウムでは活性は あまり増加しないが，メタンの選択性を減少させ炭素数 の多いオレフィン生成を増加させる。一方，白金，パラ ジウムでは活性は著しく増大するが，生成物はほとんど メタンである。しかし鉄は著しく活性が減少する。UPS, Auger の結果から, $\mathrm{Ni}-\mathrm{TiO}_{2}$ では水素で還元されたチ タニア担体からニッケルへ電子が移行していることがわ かった ${ }^{86)}$ 。

担持パラジウム触媒では，パラジウムの金属粒子が小 さくて一酸化炭素の吸着が弱いとメタノールが合成しや すく, 一方メタンの合成は, 担体表面の酸点濃度と強く 関連している。表 12 に示すように, $\mathrm{HY}, \mathrm{NaY}$ などのゼ オライト担体もしくは酸性シリカでは生成物はメタンで あるが，中性シリカ担体では，メタノールを高い選択率 で合成する ${ }^{87)}$ 。

$200 \sim 250{ }^{\circ} \mathrm{C}, 1 \sim 10$ 気圧の反応条件で, $\mathrm{Ru}-\mathrm{SiO}_{2}$ 触媒 ではメタントアセトアルデヒドが生成し, $\mathrm{Ru}-\mathrm{Al}_{2} \mathrm{O}_{3}$ 触媒 ではメタンとメタノールが生成する。Bell らは原料ガス として $\mathrm{H}_{2}$ または $\mathrm{D}_{2}$ を用い, その反応速度に与える同 位体効果の解析より, アルデヒドは, 解離 $\mathrm{CO}$ 吸着種の 水素化により生じたメチル基に CO が挿入しアセチル基 が生じ，アセチル中間体の還元的脱離で生成するとし， 一方メタノールは分子状 $\mathrm{CO}$ 吸着種の水素化によりホル 
Table 12 Activity and selectivity of palladium catalysts.

\begin{tabular}{|c|c|c|c|c|c|c|}
\hline \multirow{2}{*}{ Catalyst } & \multirow{2}{*}{$\begin{array}{l}\text { Rate }{ }^{\mathrm{a})} \text { of } \mathrm{CO} \text { consumption } \\
\left(\mathrm{moles} \mathrm{h}^{-1} \mathrm{~kg}^{-1}\right. \\
\text { of catalyst }\end{array}$} & \multicolumn{3}{|c|}{ Selectivity $^{\mathbf{a}}($ mole $\%)$} & \multicolumn{2}{|c|}{$N \times 10^{3 \mathrm{~b})}$} \\
\hline & & $\mathrm{CH}_{4}$ & $\mathrm{CH}_{3} \mathrm{OH}$ & DME & $N_{\mathrm{co}}$ & $N_{\mathrm{CH}_{4}}$ \\
\hline $2.4 \% \mathrm{PdNaY}$ & $0.08 \pm 0.03$ & 100 & - & - & $12 \pm 4$ & $12 \pm 4$ \\
\hline $5.4 \% \mathrm{PdHY}$ & $1.15 \pm 0.01$ & 98 & 2 & trace & $42 \pm 3$ & $41 \pm 3$ \\
\hline $1.7 \% \mathrm{Pd} / \mathrm{SiO}_{2}{ }^{\mathrm{c})}$ & $0.06 \pm 0.03$ & 100 & - & - & $1.7 \pm 0.8$ & $1.7 \pm 0.8$ \\
\hline $4.8 \% \mathrm{Pd} / \mathrm{SiO}_{2}{ }^{\mathrm{c})}$ & $0.07 \pm 0.03$ & 100 & - & - & $1.1 \pm 0.4$ & $1.1 \pm 0.4$ \\
\hline $4.6 \% \mathrm{Pd} / \mathrm{SiO}_{2}{ }^{\mathrm{d})}$ & $1.56 \pm 0.01$ & 3.5 & 96.5 & - & $18.8 \pm 0.1$ & $0.65 \pm 0.02$ \\
\hline $3.8 \% \mathrm{Pd} / \mathrm{Cab}-\mathrm{O}-\mathrm{Sil}$ & $0.935 \pm 0.01$ & 24 & 75 & 1 & $5.1 \pm 0.1$ & $1.2 \pm 0.02$ \\
\hline
\end{tabular}

a) $280 \pm 5^{\circ} \mathrm{C}, 15$ atm $\mathrm{H}_{2} / \mathrm{CO}(2.8-2.4), \mathrm{SV}=1,200 \pm 200 \mathrm{~h}^{-1}$.

b) $N=$ Molecules consumed (or produced)/Metal Site $\times$ sec.

c) Davison grade 01, pH $3.6 \sim 3.9\left(4 \mathrm{wt} \%\right.$ in $\left.\mathrm{H}_{2} \mathrm{O}\right)$.

d) Davison grade 57, pH 6.3 6.7 (4 wt \% in $\left.\mathrm{H}_{2} \mathrm{O}\right)$. DME : dimethyl ether

ミル基が生じ，さらに水素化されメトキシ基になり，そ のメトキシ中間体の還元的脱離により生成すると報告し ている ${ }^{88)}$ 。

このように，炭化水素合成および含酸素化合物合成と もに, 担体効果の研究が現在精力的に進められている。 今後, 合金, アルカリ金属, 担体, 粒子サイズ, 細孔構 造などを適当に組み合わせ，画期的な触媒がつぎつぎと 発見されることが強く期待されている。

\section{6. 反応因子の選択制御}

反応因子は装置設計の必要上, 実験速度式とともにか なり整理されている ${ }^{89,90)}$ 。特に連鎖成長の制御, オレフ

Table 13 Dependencies of the rates for the synthesis of $\mathrm{C}_{1}$ through $\mathrm{C}_{10}$ Hydrocarbons on the partial pressures of $\mathrm{H}_{2}$ and $\mathrm{CO}^{\mathrm{a}}$.

\begin{tabular}{c|c|c|c|c|c|c}
\hline \multirow{2}{*}{$\mathrm{C}_{\mathrm{n}}$} & \multicolumn{3}{|c|}{ Olefin } & \multicolumn{3}{c}{ Paraffin } \\
\cline { 2 - 7 } & $m$ & $n$ & $\% \mathrm{Dev}^{\mathrm{b})}$ & $m$ & $n$ & $\% \mathrm{Dev}^{\mathrm{b})}$ \\
\hline $\mathrm{C}_{1}$ & - & - & - & 1.31 & -0.96 & 7.7 \\
$\mathrm{C}_{2}$ & 0.82 & -0.73 & 4.8 & 1.45 & -0.85 & 7.7 \\
$\mathrm{C}_{3}$ & 0.80 & -0.55 & 3.2 & 1.37 & -0.49 & 4.9 \\
$\mathrm{C}_{4}$ & 0.74 & -0.47 & 3.0 & 1.21 & -0.46 & 3.3 \\
$\mathrm{C}_{5}$ & 0.53 & -0.36 & 8.1 & 0.86 & -0.24 & 2.3 \\
$\mathrm{C}_{6}$ & 0.47 & -0.28 & 6.3 & 1.11 & -0.32 & 13.5 \\
$\mathrm{C}_{7}$ & 0.35 & -0.19 & 9.3 & 0.94 & -0.24 & 5.9 \\
$\mathrm{C}_{8}$ & 0.31 & -0.15 & 11.5 & 0.91 & -0.27 & 7.9 \\
$\mathrm{C}_{9}$ & 0.20 & -0.05 & 12.3 & 0.50 & -0.18 & 19.4 \\
$\mathrm{C}_{10}$ & 0.17 & -0.01 & 15.4 & 0.93 & -0.35 & 11.4 \\
\hline
\end{tabular}

a) Reaction conditions : $\mathrm{T}=498 \mathrm{~K} ; \mathrm{P}=1-10 \mathrm{~atm} ; \mathrm{H}_{2} / \mathrm{CO}=1-3$.

b) Average deviation between predicted and observed rates.
ィン/パラフィン比の向上,メタン生成の抑制に向けて研 究が進んでいる。反応温度を低くし, 全圧を増し,水素/ 一酸化炭素比を小さくすると連鎖成長は進みやすい。す なわち, 表面の一酸化炭素濃度を増加させる方向と一致 する ${ }^{2,35,84)}$ 。表 13 に示すように, 炭素数の多い炭化水素 ほど水素の次数および一酸化炭素の負の次数の絶対值は 小さくなり，またオレフィンの方が同じ炭素数のパラフ インより水素の分圧依存性は減少する ${ }^{35,89)}$ 。第 3 物質の エチレンを少量添加すると, 図 3 に示すように生成物分 布は大きく変化する。この方法はメタノール添加と並ん で研究されつつある14,15)。

（昭和 57 年 7 月 12 日受理）

\section{文献}

1) C.K. Rofer-Depoorter, Chem. Rev., 81, 447 (1981)

2) 荒井弘通, 油化学, 27, 491 (1978)

3）市川 勝, 表面, 19, 555 (1981)

4) 日特開 昭 55-85530 (IFP)

5) D. L.King, J.A. Cusumano, R. L. Garten, Catal. Rev., 23, 233 (1981)

6) H.H.Storch, N. Columbic, R. B. Anderson, The Fischer-Tropsch and Related Synthesis, Wiley, New York, 1951

7) M.E.Dry, Catalysis, Vol.1, Springe-Verlag 1981, p. 159

8) H.H.Kung, Catal. Rev., 22, 235 (1980)

9) G.A.Mills, F.W.Steffgen, ibid., 8, 159 (1973)

10）溝呂木 勉, 触媒, 19, 90 (1977)

11）佐伯憲治, ペトロテック，3，608 (1980)

12) 出口 隆, 高野哲雄, 石野 勝, 中村収三, 触媒, 23, 18 (1981) 
13) E.L.Muetterties, J.Stein, Chem. Rev., 79, 479 (1979)

14) D. J.Dwyer, K. Yoshida, G.A. Somorjai, Hydrocarbon Synthesis from Carbon Monoxide and Hydrogen, Adv. Chem. Ser., 178, (1979) p. 65

15) V.Ponec, Catal. Rev., 18, 151 (1978)

16) G.Henrici-Olivé, S. Olivé, J. Mol. Catalysis, 3, $443(1977 / 78)$

17) R.W. Joyner, J. Catal., 50, 176 (1978)

18) R.C. Brady III, R.Pettit, J. Am. Chem. Soc., 102, 6181 (1980)

19) R. C. Brady III, R.Pettit, ibid., 103， 1287 (1981)

20）川口 襄, 触媒, 23，34 (1981)

21) D. Fraenkel, B.C.Gates, J. Am. Chem. Soc., 102, 2478 (1980)

22) H.H.Nijs, P. A. Jacobs, J.B. Uytterhoeven, $J$. Chem. Soc., Chem. Commun., 1979, 180

23) H.H.Nijs, P. A. Jacobs, J. B. Uytterhoeven, ibid., 1979, 1095

24) P.D. Caeser, J. A. Brennan, W.E. Garwood, J. Ciric, J. Catal., 56, 274 (1979)

25) C.D. Chang, W.H. Lang, A.Silvestri, J. Catal., 56, 268 (1979)

26) C.D. Chang, J. C. W. Kuo, W. H. Lang, S. M. Jacob, J. J. Wise, A. J. Silvestri, Ind. Eng. Chem., Process Res. Dev., 17, 255 (1978)

27) P.V.Venuto, P.S. Landis, Adv. Catal., 18, 308 (1968)

28) R.I.Bery, Chem. Ind., 1980, 86

29) N.Y.Chen, W.W. Kaeding, F.G. Dwyer, J. Am. Chem. Soc., 101, 6783 (1979)

30) E. M. Flanigen, Proc. Fifth Intern. Confer. ence on Zeolite, Hyden, 1980, p. 760

31）荒井弘通, 表面科学, 2, 18 (1981)

32）奥原敏夫，御園生誠，表面，18，357（1980）

33) H.Arai, H.Tominaga, J. Catal., 43, 131 (1976)

34) G. Broden, T.N. Rhodin, C. Brucker, Surf. Sci., 59, 593 (1976)

35) A.T.Bell, Catal. Rev., 23, 203 (1981)

36) E.Miyazaki, J. Catal., 65, 84 (1980)

37）宮崎栄三，表面，19，259（1981）

38) I. Toyoshima, G.A. Somorjai, Catal. Rev., 19, 105 (1979)

39) C.M. Varma, A.J.Wilson, Phys. Rev., B 22, 3795 (1980)

40) J.A.Rabo, A.P. Risch, M.L.Poutsma, J. Catal., 53, 295 (1978)

41) N.V.Richardson, A.M. Bradshaw, Surf. Sci., 88, 255 (1979)

42) M. A. Beno, J. M. Williams, M. Tachikawa, E. L. Muetterties, J. Am. Chem. Soc., 103, 1485 (1981)
43) V.Ponec, Ind. Eng. Chem. Prod. Res. Dev., 18, 268 (1979)

44) R.Eisemberg, D.E.Hendricksen, Adv. Catal., 28, 79 (1979)

45) C.P.Casey, S. M. Neumann, M.A.Andrews, D. R. McAlister, Pure Appl. Chem., 52, 625 (1980)

46) N.E. Kim, W. J. Nelson, D.F. Shriver, Inorg. Chim. Acta, 7, 393 (1973)

47) J.F.Kristoff, Inorg. Chem., 13, 499 (1974)

48) C.P.Casey, S.M.Neumann, J. Am. Chem. Soc., 98, 5395 (1976)

49) A.L.Dent, R. J.Kokes, J. Phys. Chem., 73, 3772, 3781 (1969)

50) R.G.Herman, K. Klier, G. W.Simmons, B.P. Finn, S. B. Bulko, J. Catal., 56, 407 (1979)

51) S. Mehta, G. W.Simmons, K. Klier, R. G. Herman, ibid., 57, 339 (1979)

52) G. Carnisio, F. Garbassi, G.Petrini, G. Parravano, ibid., 54, 66 (1978)

53) T. V. Belysheva, F.S. Shub, V.D.Kuznetsov, M.I. Temkin, Kinet. Catal (Engl. Transl.), 19, 296 (1978)

54) M. L.Poutsma, L.F. Elek, P. A. Ibarbia, A.D. Risch, J.A.Rabo, J. Catal., 52, 157 (1978)

55) K. L. Brown, G. R. Clark, C.E. L. Headford. K. Marsden, W.R.Roper, J. Am. Chem. Soc., 101, 503 (1979)

56) H.Arai, J. Catal., 51, 135 (1978)

57) H. Froitzheim, H. Ibach, S. Lehwald, Surf. Sci., 63, 56 (1977)

58) J.Halpern, Adv. Catalysis, 11, 301 (1959)

59) P. J.Lucchesi, J.L. Carter, J. H. Sinfelt, J. Am. Chem. Soc., 86, 1494 (1964)

60) M.Boudart, M.A. Vannice, J.E.Z.Benson, Phys. Chem. (Wiesbaden), 64, 171 (1964)

61) E. Keren, A.Soffer, J. Catal., 50, 43 (1977)

62) N. Nahon, V.Perrichon, P.Turlier, P. Bussiére, React. Kinet. Catal. Lett., 11, 281 (1979)

63）荒井弘通, 化学工場, 25，86 (1981)

64) D.A.Dowden, N. Mackenzie, B.M.W. Trapnell, Proc. Roy. Soc., A 239, 245 (1956)

65) J.H.Sinfelt, Catal. Rev., 9, 147 (1974)

66) J.H.Sinfelt, J.A.Cusumano, Advanced Materials in Catalysis, Academic Press, New York, 1977, p. 1

67) J.H.Sinfelt, J. Catal., 29, 308 (1973)

68) W.M.H.Sachtler, Adv. Catal., 26, 69 (1977)

69) M.Araki, V.Ponec, J. Catal., 44, 439 (1976)

70) M. Nakamura, B.J. Wood, P.Y.Hou, H. Wise, Proc. 7 th Intern. Congr. Catal., 1980, Vol. 1, p. 432 
71) R.M.Stanfield, W.N.Delgass, J. Catal., 72, 37 (1981)

72) E.E. Unmuth, L.H. Schwartz, J. B. Butt, ibid., 63, 404 (1980)

73) D. J.Elliott, J.H. Lunsford, ibid., 57, 11 (1979)

74) G. L.Ott, T.Fleisch, W.N.Delgass, ibid., 60, 394 (1979)

75) G.A.Somorjai, Catal. Rev., 23, 189 (1981)

76) A. Ozaki, K.Aika, Catalysis, Vol. 1, Springe-Verlag, 1981, p. 87

77) G. Brodén, G. Gafner, H.P. Bonzel, Surf. Sci., 84, 295 (1979)

78) G.B.McVicker, M.A. Vannice, J. Catal., 63, 25 (1980)

79) M.E.Dry, J.A. K. du Plessis, G. M. Leuteritz, ibid., 6, 194 (1966)

80) M.E.Dry, Brennstoff-Chemie, 50, 193 (1969)

81) K. K. Kishi, M.W. Roberts, J. Chem. Soc.,
Faraday Trans. I, 71, 1715 (1975)

82) M.A. Vannice, R. L. Garten, J. Catal., 63, 255 (1980)

83) C.H. Bartholomew, R. B. Pannell, J. L. Butler, D. G. Mustard, Ind. Eng. Chem. Prod. Res. Dev., 20, 296 (1981)

84) C.H. Bartholomew, R. B. Pannell, J. L. Butler, J. Catal., 65, 335 (1980)

85) M.A. Vannice, R. L. Garten, ibid., 56, 236 (1979)

86) Chia-Chieh Kao, Shou-Chin Tsai, YipWah Chung, ibid., 73, 136 (1982)

87) F. Fajula, R. G. Anthony, J.H. Lunsford, ibid., 73, 237 (1982)

88) C.S. Kellner, A.T.Bell, ibid., 71, 288 (1981)

89) C.S. Kellner, A.T.Bell, ibid., 70, 418 (1981)

90) M. M. Bhasin, W. J. Bartley, P.C. Ellgen, T. P. Wilson, ibid., 54, 120 (1978)

\section{取 引 銀 行 口 座}

本協会の取り引き銀行は第一勧業銀行 飯倉支店です。会費など本会宛のご送金は下記へ打振り込み下さいます 様に扮願い申し上げます。

○ 取引銀行

\section{第一勧業銀行 飯倉支店}

普通預金口座Ｎo．058-1000014 